\title{
Hydrogeochemical modelling to understand the surface water-groundwater interaction around a proposed uranium mining site
}

\author{
S ManoJ, M Thirumurugan and L Elango*®o \\ Department of Geology, Anna University, Chennai, Tamil Nadu 600 025, India. \\ *Corresponding author.e-mail: elango34@hotmail.com
}

MS received 7 February 2018; revised 11 May 2018; accepted 12 June 2018; published online 23 February 2019

The interaction between surface water and groundwater is a complex process and is considered as an important component for controlling the mining activities. The objective of this study is to understand the interaction between surface water and groundwater around a proposed uranium mining site by geochemical modelling. Surface water and groundwater samples along the groundwater flow path were collected from September 2013 to June 2016 across the uranium mineralised region located near Gogi, Karnataka, India. Collected water samples were analysed for major ion and uranium concentrations. This hydrochemical data was used as input in the geochemical modelling code PHREEQC to calculate the uranium speciation and saturation indices. Inverse geochemical modelling was performed along the flow direction by considering the mineralogical composition of host rock. Measurement of surface water and groundwater level indicates that the recharge and discharge of this region were primarily controlled by rainfall. Relation between the temporal variation of rainfall and saturation index of mineral reveals the various scenarios of interaction between surface water and groundwater around the mineralised region. Silicate/carbonate weathering, irrigation return flow and dissolution of evaporites are the major processes indicated by inverse geochemical modelling, which controls the hydrogeochemical evolution of water in this region. Geochemical modelling was effectively used to understand the temporal changes in the interaction between surface water and the groundwater in a uranium mineralised region.

Keywords. Uranium; Bhima basin; PHREEQC; geochemical speciation; saturation index; inverse modelling.

\section{Introduction}

Mineral exploitation plays a major role in world's economic and industrial development. It guarantees the continuous supply of raw materials to the construction and manufacturing sectors for the economic development of the country (Hein et al. 2004). Uranium is one such raw material, extracted through conventional mining and is used to generate nuclear energy. Due to rise in demand and depletion of existing uranium reserves, it becomes essential to find new deposits and also increase the production of the existing deposits (Mason 2014). In general, mining of economic minerals induces significant changes in surface hydrology, groundwater systems and water quality (Booth 2006). Diversion of surface water, creation of additional ponds, changes in stream alignment, interaction between surface water and groundwater as well as changes in water quality are some of the challenges need to be addressed during mining (Kay et al. 2006). Vance et al. (2014) compared the currently leading approaches of managing environmental and health impacts of uranium mining 
with the outdated practices which suggest that innovative, modern mining practices combined with strictly enforced regulatory standards will reduce the environmental and health risks caused due to mining.

Understanding the interaction between surface water and groundwater is one such essential step for the optimal management of regional water resources during mining operations. In mining areas, extra care was taken to maintain the quality as well as regional fluctuation in the water table to preserve the surface water and groundwater ecosystem (ANZECC 2000). The interaction of groundwater with adjoining lakes, reservoirs, streams and canals is the major aspect that governs the inflow, outflow and flow direction of the region. Numerous studies based on stable isotopes (Katz et al. 1997; Paces and Wurster 2014; Alaaho et al. 2015), hydrochemistry (Soulsby et al. 2005; Ayenew et al. 2008; Martinez et al. 2015) and modelling (Pahar and Dhar 2014; Voeckler et al. 2014; Hu et al. 2016; Yi et al. 2016) were widely applied to understand the surface water and groundwater interactions. Apart from these, hydrogeochemical evolution from surface water to groundwater through the unsaturated zone using inverse modelling have been carried out by various researchers (Lecomte et al. 2005; Federico et al. 2008; Sharif et al. 2008; Belkhiri et al. 2010) to understand the geochemical evolution of water and the process responsible for the evolution. Eary et al. (2003) also assessed the water quality changes in connection with the mining operations using the inverse modelling and Brindha and Elango (2014) have used the geochemical modelling to understand the geochemical changes in groundwater due to leaching from uranium tailing ponds.

Uranium exploration in India dates back from early 1950s and the deposits belongs to the Proterozoic age has been considered as the potential target (Chaki et al. 2005). Bhima basin is one among the seven Purana basins (Palaeoproterozoic-Neoproterozoic age) in Indian peninsula (Kale and Phansalkar 1991), which is characterised by seven major faults (Kale and Peshwa 1995) in which the medium grade of uranium deposits occurs around one of them (Achar et al. 2001). Investigations in the Bhima basin were carried out by an integrated approach with several exploration techniques was adopted and the extent of uranium reserve in this region was estimated (Achar et al. 2001). This uranium deposit is structurally controlled and of hydrothermal vein type (Chaki et al.
2011). To meet the increasing demand of uranium, it is planned to mine uranium ore from this area in future. Manoj et al. (2017a, b) assessed the concentration of uranium in groundwater of the entire Shahpur taluk which ranged from below determination level $(<0.05 \mathrm{ppb})$ to $302 \mathrm{ppb}$.

Hydrogeochemical methods are commonly used to establish the relationship between the surface water and groundwater and the mechanism involved in the geochemical evolution. Hydrogeochemical methods based on the concentration of ions in water and saturation indices of minerals provide a cost-effective alternative to understand the groundwater recharge and flow processes over a large area. As this region with uranium deposit has two large lakes with complex hydrogeological setup, it is necessary to understand the interaction between the surface water and groundwater. In addition, this study will serve as the baseline data which will be helpful to assess the present and future impacts from mining that can possibly influence the hydrogeology and geochemistry of the surface water and groundwater of this region. Thus, the objective of this study is to understand the interaction between surface water and groundwater in the uranium mineralised Gogi region, Karnataka, India, by geochemical modelling.

\section{Study area}

The study area lies in the southern part of the Bhima basin, which is located around $12 \mathrm{~km}$ west of Shahpur, Yadgir district of Karnataka, India. The geographical extent of the study area is about $14 \mathrm{~km}^{2}$ with 1571 houses and about 10,000 residents as per the 2011 census (Chandramouli and General 2011). The area experiences three seasons: (i) summer from late February to mid-June, (ii) southwest monsoon from mid-June to late September and (iii) dry winter until January, where the temperature ranges from $37^{\circ}$ to $46^{\circ} \mathrm{C}, 25^{\circ}$ to $37^{\circ} \mathrm{C}$ and $12^{\circ}$ to $32^{\circ} \mathrm{C}$, respectively (Karunakara et al. 2014). The average annual rainfall in this area is about $839 \mathrm{~mm}$ and most of the precipitation occurs during the southwest monsoon. The surface runoff resulted in the development of dentritic drainage pattern in this area. Two major lakes namely Melinakere (L1 lake) and Kelaginakere (L2 lake) are present in the upstream and downstream of the mineralised zones, respectively. These lakes support the water demand for domestic and agricultural purposes in the study area (figure 1). 


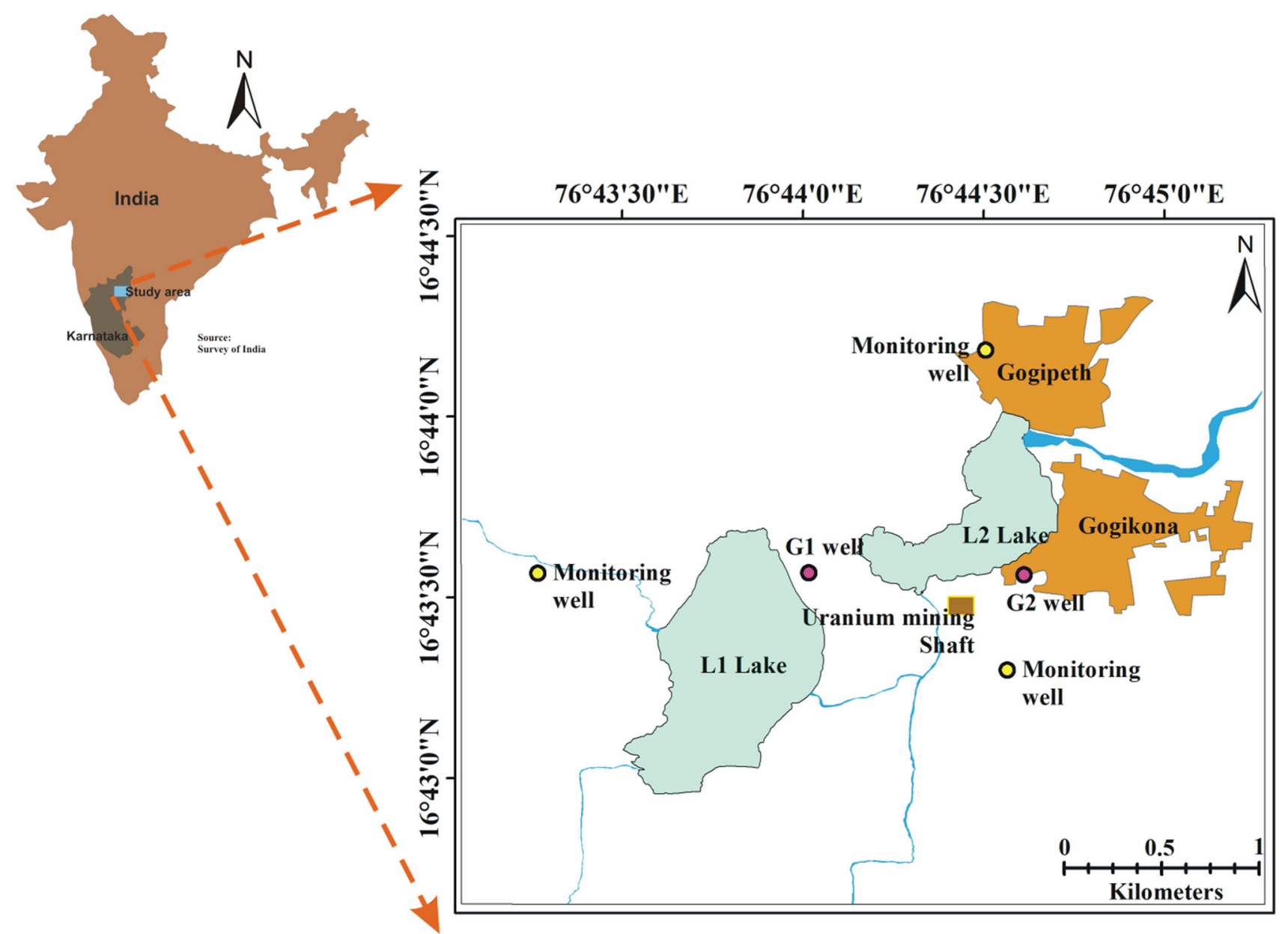

Figure 1. Study area.

The cropping pattern depends on three seasons namely kharif, rabi and summer. The kharif cropping season is from July to October during the southwest monsoon and the rabi cropping season is from October to March. The crops grown between March and June are summer crops. The crops covered in this area are kharif: paddy, jowar, tur, cotton, and sunflower; rabi: jowar, wheat and bengal gram; and summer: paddy and groundnut.

\section{Uranium mineralisation and geology of Gogi region}

In India, most of the uranium deposits fall under the low-grade category, which include the deposits in the states of Jharkhand, Chhattisgarh, Meghalaya, Andhra Pradesh, Rajasthan and Haryana. The Gogi uranium deposit in the state of Karnataka is of the higher quality (medium grade) among the ores found in the rest of the country (Chaki et al. 2011). Based on the available lithologs, the cross-section along the Gogi uranium mineralised zone was arrived (figure 2). Uranium mineralisation in Gogi region occurs within the major E-W trending Gogi-Kurlagere fault (Karunakara et al. 2014), passing through the mineralised zone, which takes a NE swerve near the south of Gogi lake and attains easterly trend near the north of the Gogi village (Achar et al. 2001). Chaki et al. (2005) reported that the mineralisation is steeply dipping and the fault is reverse in nature. The strike of the reverse fault is $\mathrm{N} 50^{\circ} \mathrm{E}-\mathrm{S} 50^{\circ} \mathrm{W}$ and is dipping towards $\mathrm{S} 40^{\circ} \mathrm{E}$. Intense brecciation in limestone, steeply dipping beds and basement granites are the characteristic features of the fault zone indicating the involvement of basement rocks during tectonisation. Uranium occurring in uraninite is hosted mainly in sheared phosphatic limestone, non-phosphatic limestone and basement granite present in this region. During the drilling by Atomic Mineral Directorate, the surface samples collected contain $0.017-0.084 \%$ and $0.02-$ $0.27 \%$ of $\mathrm{U}_{3} \mathrm{O}_{8}$ in phosphatic and non-phosphatic 


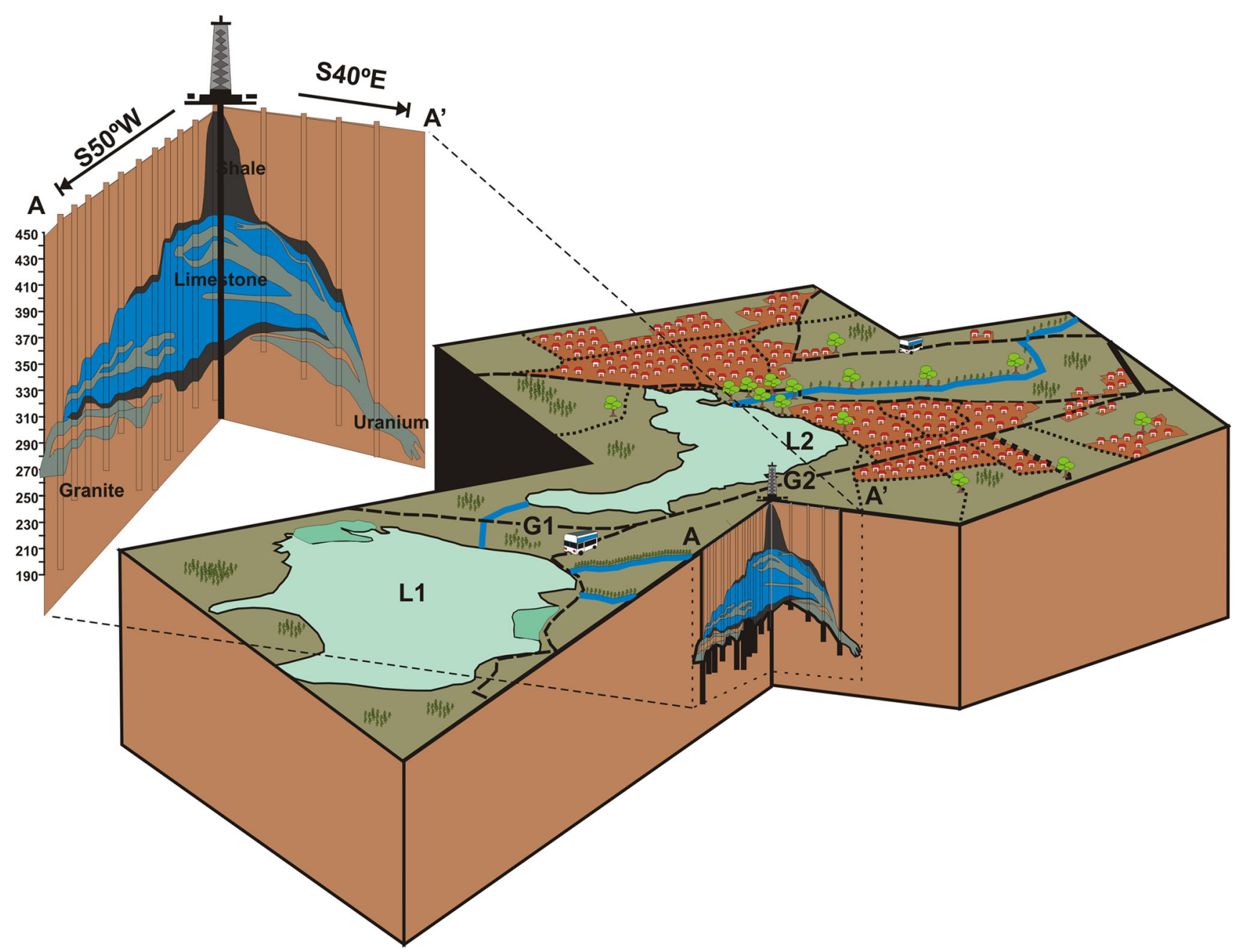

Figure 2. Cross-section across the uranium mineralised zone (after Chaki et al. 2005, 2011).

limestones, respectively, whereas some of the core samples of granitic terrain contain up to $20 \%$ of $\mathrm{U}_{3} \mathrm{O}_{8}$ (Chaki et al. 2005). Mineralisation in granite close to the unconformity contact shows radiometric assay of $0.02-0.3 \% \mathrm{U}_{3} \mathrm{O}_{8}$ (Achar et al. 2001). Uranium in this region is apparently derived from hydrothermal leaching of basement granite rock and deposited in the fault zone near to the contact of carbonate rocks due to the favourable geochemical environment of uranium precipitation (Senthil and Srinivasan 2002).

\section{Methodology}

\subsection{Sample collection}

Surface water (L1 and L2) from the two lakes and groundwater (G1 and G2) from the nearby wells were collected so as to approximately represent the general groundwater flow direction (figure 2).
Water sampling was carried out once in 3 months from September 2013 to June 2016. Geologically, L1 and G1 fall in granitic terrain, whereas L2 and G2 fall in carbonate terrain. The aim and purpose of choosing this location is to understand the geochemical variation during the migration of water from granitic terrain to carbonate terrain. Collected water samples were filtered through $0.45 \mu \mathrm{m}$ and transferred to the laboratory for the analysis of major ions and uranium concentration.

\subsection{Hydrogeochemical characterisation}

The $\mathrm{pH}$, electrical conductivity (EC), temperature and redox potential (Eh) of surface water and groundwater were measured in the field using portable multiparameter system (Eureka Sub Manta-2) and the concentrations of carbonate and bicarbonate were estimated using the Merck alkalinity test kit (111109). Cations $\left(\mathrm{Ca}^{2+}, \mathrm{Mg}^{2+}, \mathrm{Na}^{+}\right.$ and $\left.\mathrm{K}^{+}\right)$and anions $\left(\mathrm{Cl}^{-}, \mathrm{SO}_{4}^{-}\right.$and $\left.\mathrm{NO}_{3}^{-}\right)$were 
analysed in the laboratory from the filtered water samples using ion chromatograph (IC Metrohm 861). Ion balance error was calculated and was found to be within $\pm 10 \%$. The concentration of uranium in water samples was analysed using a laser fluorimeter (Quantalase LF-2a). This method measures the fluorescence of uranium complex in the water sample by excitation under ultraviolet light. The fluorescence of uranium complexes is measured by a sensitive photomultiplier tube. The accuracy of analysis was achieved through the measurement of certified standard reference solution ICP-MS-66N and the precision was established by duplicate analysis of every two samples.

\subsection{Measurement of surface water and groundwater levels}

Water level fluctuation in surface water bodies, as well as subsurface, is a primary tool to understand the degree of interaction between surface water and groundwater. Aquifer system readily reacts to the changes that take place during the recharge and discharge of water with respect to time and season. In order to understand the mechanism of the interaction process, the water level in the lakes was measured using a scale fixed at a place with the known elevation and the groundwater level was measured during the sampling campaign using the water level indicator (Solinist 101) in the wells (G1 and G2) adjacent to the lakes and in three more wells located around the mineralised zone. Based on the measured surface water and groundwater level, groundwater table map was prepared using ArcGIS 10.1 software for different time periods.

\section{Geochemical modelling}

\subsection{Species calculation and saturation index}

Uranium occurs as $\mathrm{U}^{4+}, \mathrm{U}^{5+}$ and $\mathrm{U}^{6+}$ ion in natural water; however, from geochemical point of view, the oxidation states of $\mathrm{U}^{4+}$ and $\mathrm{U}^{6+}$ ions were dominant (Dongarra 1984). $\mathrm{U}^{4+}$ occurs in the form of hydroxides, hydrated fluorides and phosphates, whereas $\mathrm{U}^{6+}$ is the most stable state occurring in the form of $\mathrm{U}_{3} \mathrm{O}_{8}$ (uraninite). The distribution of aqueous uranium species in surface water and groundwater of this region was calculated based on geochemical data using PHREEQC (Parkhurst 1995). Temperature, $\mathrm{pH}, \mathrm{Eh}$, and concentrations of ions are the essential data used as an input for the species calculation.
The saturation index (SI) was applied to predict the reactive mineralogy of the subsurface from the groundwater sample data without collecting the samples of the solid phase (Rajmohan and Elango 2004). The SI was calculated using the computer geochemical program PHREEQC for surface water and groundwater samples. It is defined as

$$
\mathrm{SI}=\log \frac{\mathrm{IAP}}{K_{\mathrm{eq}}},
$$

where IAP is the ion activity product and $K_{\text {eq }}$ is the equilibrium constant. Equilibrium is indicated when SI $=0$, the water is supersaturated when SI $>0$. If SI $<0$, the water is undersaturated.

\subsection{Inverse geochemical modelling}

Inverse modelling calculates the transfer of moles (minerals/gases) that tend to dissolve or precipitate, and it also explains the chemical changes between the known initial and final solutions with respect to the available mineral phases. This is essential in understanding the causes for the transformation of chemical composition within the groundwater and surface water. To evaluate the geochemical evolution and chemical reactions along the flow direction, inverse modelling was carried out using PHREEQC. Mass balance calculation along a specific flow path was performed in the inverse modelling. During this inverse geochemical modelling, it was assumed that (i) the initial and final solutions represent the flows along the same flow direction, (ii) dispersion/diffusion do not affect the chemistry of water, and (iii) the mineral phases used in the model are exactly present in the aquifer. The modelling was carried out with the measured chemical composition of waters and the initial and final waters were L1-G1, G1-G2 and G2-L2 for all the sampling periods. That is the chemical composition of the surface water (L1/L2) and groundwater (G1/G2) represents the initial and final solutions for inverse geochemical modelling. The mineral phases that are likely to be present between these locations were also considered. Mineral phases included in the inverse modelling are obtained from the field observation and the geochemical studies were carried out in and around this region by Chaki et al. (2005) and Patnaik et al. (2016). The simulations were constrained within the pre-defined uncertainty limit of 0.05 (5\%) or 0.1 $(10 \%)$ as default for all the periods. By keeping the mineral phases constant, the inverse geochemical 
Table 1. Hydrogeochemistry of surface water and groundwater.

\begin{tabular}{|c|c|c|c|c|c|}
\hline \multirow[b]{2}{*}{ Parameter } & \multirow[b]{2}{*}{ Unit } & \multicolumn{2}{|c|}{ Mean } & \multicolumn{2}{|c|}{ Range } \\
\hline & & Surface water & Groundwater & Surface water & Groundwater \\
\hline $\mathrm{pH}$ & pH scale & - & - & $7.2-9.3$ & $6.8-7.9$ \\
\hline $\mathrm{EC}$ & $\mu \mathrm{S} / \mathrm{cm}$ & 1005 & 1444 & $617-1674$ & 1189-1909 \\
\hline Calcium & $\mathrm{mg} / \mathrm{l}$ & 52 & 59 & $40-82$ & $42-75$ \\
\hline Magnesium & $\mathrm{mg} / \mathrm{l}$ & 22 & 34 & $19-30$ & $10-75$ \\
\hline Sodium & $\mathrm{mg} / \mathrm{l}$ & 95 & 141 & $50-143$ & $66-255$ \\
\hline Potassium & $\mathrm{mg} / \mathrm{l}$ & 5 & 7 & $1-7$ & $1-18$ \\
\hline Bicarbonate & $\mathrm{mg} / \mathrm{l}$ & 235 & 351 & $175-341$ & $263-488$ \\
\hline Chloride & $\mathrm{mg} / \mathrm{l}$ & 113 & 175 & $65-164$ & $112-275$ \\
\hline Sulphate & $\mathrm{mg} / \mathrm{l}$ & 42 & 76 & $25-64$ & 53-106 \\
\hline Nitrate & $\mathrm{mg} / \mathrm{l}$ & 48 & 43 & $21-80$ & $28-66$ \\
\hline Uranium & $\mu \mathrm{g} / 1$ & 12 & 27 & $2-33$ & $13-52$ \\
\hline
\end{tabular}

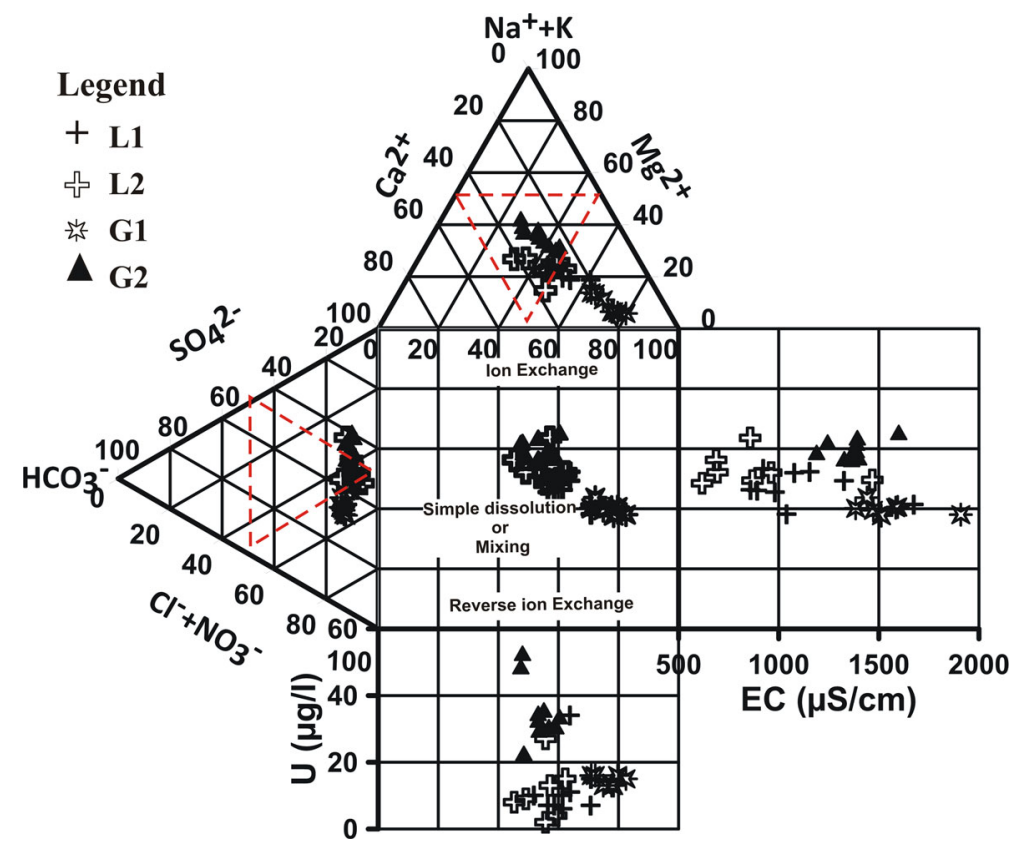

Figure 3. Hydrogeochemical facies of surface water and groundwater (Durov 1948).

modelling was carried out for all sampling periods to understand the temporal changes in the surface and groundwater interaction.

\section{Results and discussion}

\subsection{Chemical characterisation of surface water and groundwater}

The mean and range of $\mathrm{pH}, \mathrm{EC}$, calcium, magnesium, sodium, potassium, bicarbonate, chloride, sulphate and nitrate concentration in the surface water and groundwater samples collected around the uranium mineralised zone are given in table 1. The dissolved solids are comparatively high in groundwater than the surface water as indicated by EC. The concentration of nitrate alone is slightly higher in surface water, whereas rest of the major ions in groundwater is higher than surface water. Since this region is intensively cultivated and the runoff discharges into the lakes, high concentration of nitrate (Bureau of Indian Standards permissible limit $45 \mathrm{mg} / \mathrm{l}$ ) was observed in both the surface water ( $53 \%$ of samples) and groundwater ( $41 \%$ of samples). Hydrochemical facies identified by a double triangular plot (Durov 1948) (figure 3) indicates that the surface water (L1 and L2) and groundwater (G2) fall in the mixed $\mathrm{Ca}-\mathrm{Mg}-\mathrm{Cl}$ type, whereas groundwater from the 
Table 2. Percentage range of $U$ speciation in surface water and groundwater.

\begin{tabular}{llll}
\hline L. no. & Nature of water & Speciation form & $\begin{array}{c}\text { Percentage } \\
\text { range }\end{array}$ \\
\hline L1 & Lake (upstream) & $\mathrm{UO}_{2}\left(\mathrm{CO}_{3}\right)_{3}^{4-}$ & $21-91$ \\
& & $\mathrm{UO}_{2}\left(\mathrm{CO}_{3}\right)_{2}^{2-}$ & $9-77$ \\
& & $\mathrm{UO}_{2}\left(\mathrm{CO}_{3}\right)$ & $0-2$ \\
L2 & Lake (downstream) & $\mathrm{UO}_{2}\left(\mathrm{CO}_{3}\right)_{3}^{4-}$ & $9-76$ \\
& & $\mathrm{UO}_{2}\left(\mathrm{CO}_{3}\right)_{2}^{2-}$ & $24-85$ \\
& & $\mathrm{UO}_{2}\left(\mathrm{CO}_{3}\right)^{4-}$ & $0-6$ \\
G1 & Groundwater (upstream) & $\mathrm{UO}_{2}\left(\mathrm{CO}_{3}\right)_{3}^{4-}$ & $31-64$ \\
& & $\mathrm{UO}_{2}\left(\mathrm{CO}_{3}\right)_{2}^{2-}$ & $36-68$ \\
& & $\mathrm{UO}_{2}\left(\mathrm{CO}_{3}\right)$ & $0-1$ \\
G2 & Groundwater (downstream) & $\mathrm{UO}_{2}\left(\mathrm{CO}_{3}\right)_{3}^{4-}$ & $17-54$ \\
& & $\mathrm{UO}_{2}\left(\mathrm{CO}_{3}\right)_{2}^{2-}$ & $46-80$ \\
& & $\mathrm{UO}_{2}\left(\mathrm{CO}_{3}\right)$ & $0-3$ \\
\hline
\end{tabular}

G1 well was of $\mathrm{Na}-\mathrm{Cl}$ type. It indicates that the hydrogeochemistry of groundwater flow from the upstream region is transformed from $\mathrm{Na}-\mathrm{Cl}$ type to the mixed $\mathrm{Ca}-\mathrm{Mg}-\mathrm{Cl}$ type when it enters into the mineralised zone of the downstream region due to the presence of carbonate rocks and the continuous infiltration of surface water (L1).

Uranium concentration during all the sampling campaign ranges from 2 to $52 \mu \mathrm{g} / \mathrm{l}$. The mean and range of uranium concentration in surface water and groundwater are given in table 1 . The concentration of uranium is higher in groundwater when compared to surface water in most of the sampling campaigns (figure 3). The uranium concentration increases along the flow path (L1-G1-G2) and decreases in L2 (when compared with G2). An inconsistent range of uranium concentration was observed throughout the sampling campaign between flow path G2-L2, which is due to the sudden variation of $\mathrm{pH}, \mathrm{Eh}$, temperature and exposure to surface water (L2), resulting in instability of uranium complex in water.

\subsection{Geochemical speciation}

The mobility of uranium in water is controlled by uranium speciation; hence, it is important to know the dominant uranium species in order to predict its migration and distribution. Factors controlling the uranium speciation are $\mathrm{pH}$, Eh, concentration of ions/ionic strength and the different mineral phases during the interaction process (Bernhard et al. 1996). Based on PHREEQC output, the uranium tetravalent ion complex exists in various forms of species such as $\mathrm{U}(\mathrm{OH})^{5-}, \mathrm{U}(\mathrm{OH})^{4}, \mathrm{U}^{4+}$

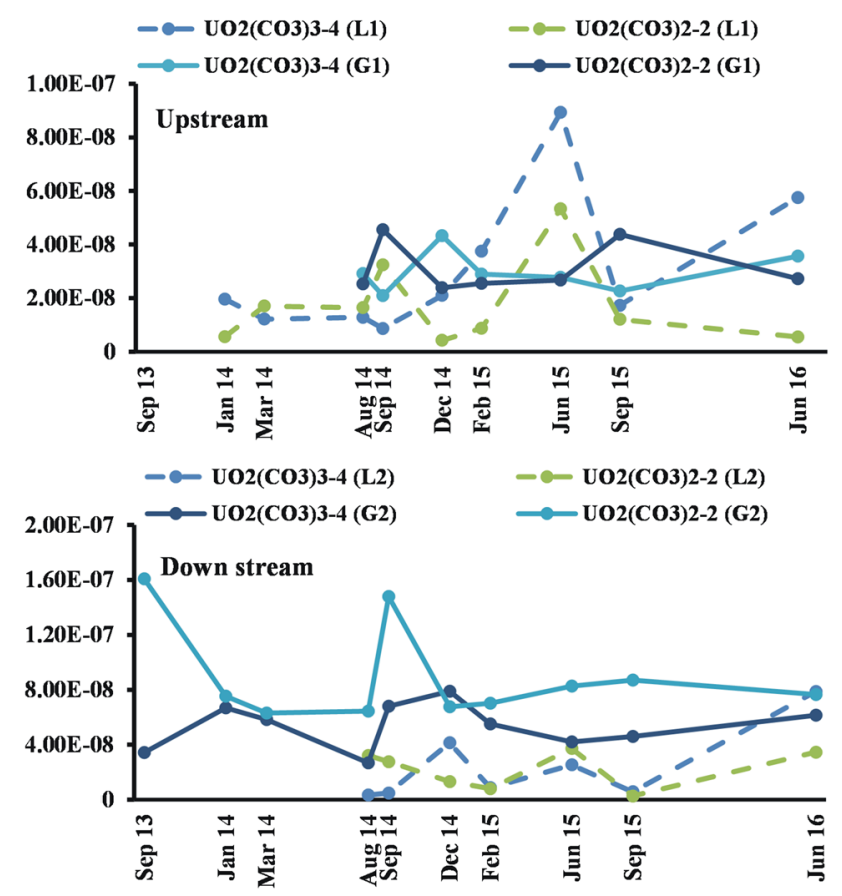

Figure 4. Temporal variation of $\mathrm{U}$ species in surface water and groundwater of upstream and downstream regions around the mineralised zone.

and uranium hexavalent complex exhibits in the form of $\mathrm{UO}_{2}\left(\mathrm{CO}_{3}\right)_{3}^{4-}, \mathrm{UO}_{2}\left(\mathrm{CO}_{3}\right)_{2}^{2-}, \mathrm{UO}_{2}\left(\mathrm{CO}_{3}\right)$, $\mathrm{UO}_{2} \mathrm{OH}^{+}, \mathrm{UO}_{2}^{2+},\left(\mathrm{UO}_{2}\right)_{2}(\mathrm{OH})_{2}^{2+},\left(\mathrm{UO}_{2}\right)_{3}(\mathrm{OH})^{5+}$. Species calculation displays that the uranium complexes of $\mathrm{UO}_{2}\left(\mathrm{CO}_{3}\right)_{3}^{4-}$ and $\mathrm{UO}_{2}\left(\mathrm{CO}_{3}\right)_{2}^{2-}$ are common in aqueous solution, whereas the complexing of the types such as $\mathrm{U}(\mathrm{OH})^{5-}, \mathrm{U}(\mathrm{OH})^{4}, \mathrm{U}^{4+}$, $\mathrm{UO}_{2}\left(\mathrm{CO}_{3}\right), \quad \mathrm{UO}_{2} \mathrm{OH}^{+}, \quad \mathrm{UO}_{2}^{2+}, \quad\left(\mathrm{UO}_{2}\right)_{2}(\mathrm{OH})_{2}^{2+}$, $\left(\mathrm{UO}_{2}\right)_{3}(\mathrm{OH})^{5+}$ were minimal in surface and groundwater of this region. Formation of uranyl carbonate complexes $\mathrm{UO}_{2}\left(\mathrm{CO}_{3}\right)_{3}^{4-}$ and $\mathrm{UO}_{2}$ 
$\left(\mathrm{CO}_{3}\right)_{2}^{2-}$ is favourable because of neutral to alkaline pH (Hsi and Langmuir 1985; Pabalan et al. 1996; Nair and Merkel 2011) of water and the weathering of carbonate rocks present in this region. Table 2 shows the percentage range of uranium species distributions in the lake and groundwater present in the upstream and downstream regions. Temporal variation of uranium species is shown in figure 4 , and it indicates that the groundwater of downstream region is abundant with uranium species due to increase in the release of uranium from the

(a)

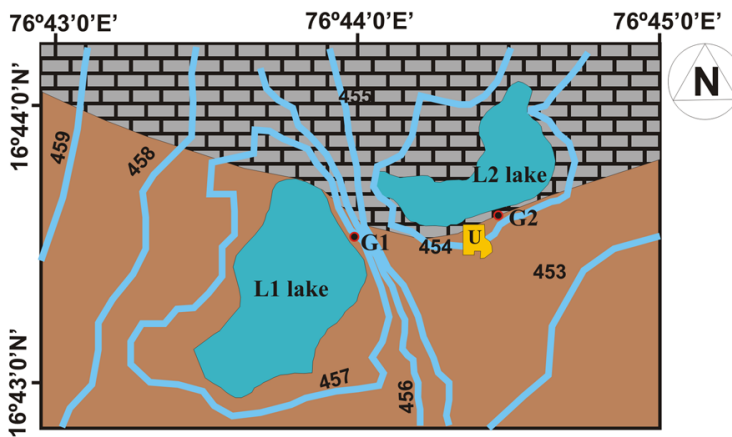

(b)
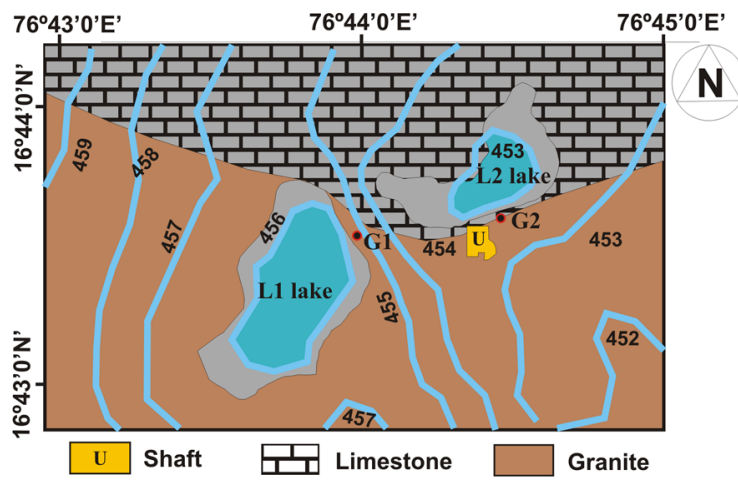

(c)
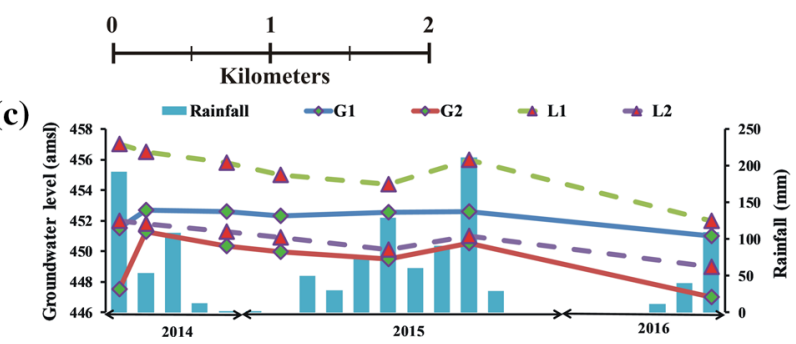

Figure 5. Spatial variation of groundwater level during (a) monsoon, (b) non-monsoon, and (c) temporal variation of surface water and groundwater levels (m amsl). mineralised zone at deeper depth along the slope direction.

\subsection{Validation of interaction based on water level fluctuations}

The groundwater level in this region ranges between 1 and $5 \mathrm{~m}$ below the ground level. L1 lake contains water throughout the year, whereas L2 lake contains water during monsoon and post-monsoon and is almost dry during summer. Discharge of surface water from upstream to downstream (L1-L2) was observed in the field during monsoon where the movement of water was clearly visualised. Based on the measured surface water and groundwater levels, the spatial and temporal variation was prepared (figure 5). Spatial and temporal variations of surface water and groundwater levels indicate that the rainfall plays a major role, which controls the recharge and discharge of this region. It also reveals that the direct runoff from the L1 lake (upstream) to the L2 lake (downstream) took place during high rainfall periods. Both the lakes were filled quickly in the beginning of monsoon itself due to increase in rainfall recharge and excess runoff from surrounding areas. During the onset of monsoon, the water level in the lakes L1 and L2 rises and the water seeps into G1 and G2, respectively. The water from the G1 further flows into G2. The groundwater level gradually rises during the monsoon to a depth less than $1 \mathrm{~m}$ from the surface. During the post-monsoon, L1 seeps into shallow groundwater (G1) from which the water flows into G2. The groundwater (G2) further flows into lake L2 due to the difference in water levels. It shows that recharge from lakes to groundwater and groundwater to lakes varies during pre-monsoon/monsoon and post-monsoon, respectively.

\subsection{Validation of interaction based on SI}

Hydrogeochemistry of surface water and groundwater is used as an input to represent the extent to which the water is chemically in equilibrium

Table 3. Minimum and maximum of calculated mineral SI.

\begin{tabular}{lllllll}
\hline & & \multicolumn{2}{c}{ Minimum } & & \multicolumn{2}{c}{ Maximum } \\
Phase & Composition & Lake & Groundwater & & Lake & Groundwater \\
\hline Calcite & $\mathrm{CaCO}_{3}$ & -0.26 & -0.27 & & 1.31 & 0.47 \\
Dolomite & $\mathrm{CaMg}\left(\mathrm{CO}_{3}\right)_{2}$ & -0.57 & -0.52 & & 2.61 & 0.9 \\
\hline
\end{tabular}



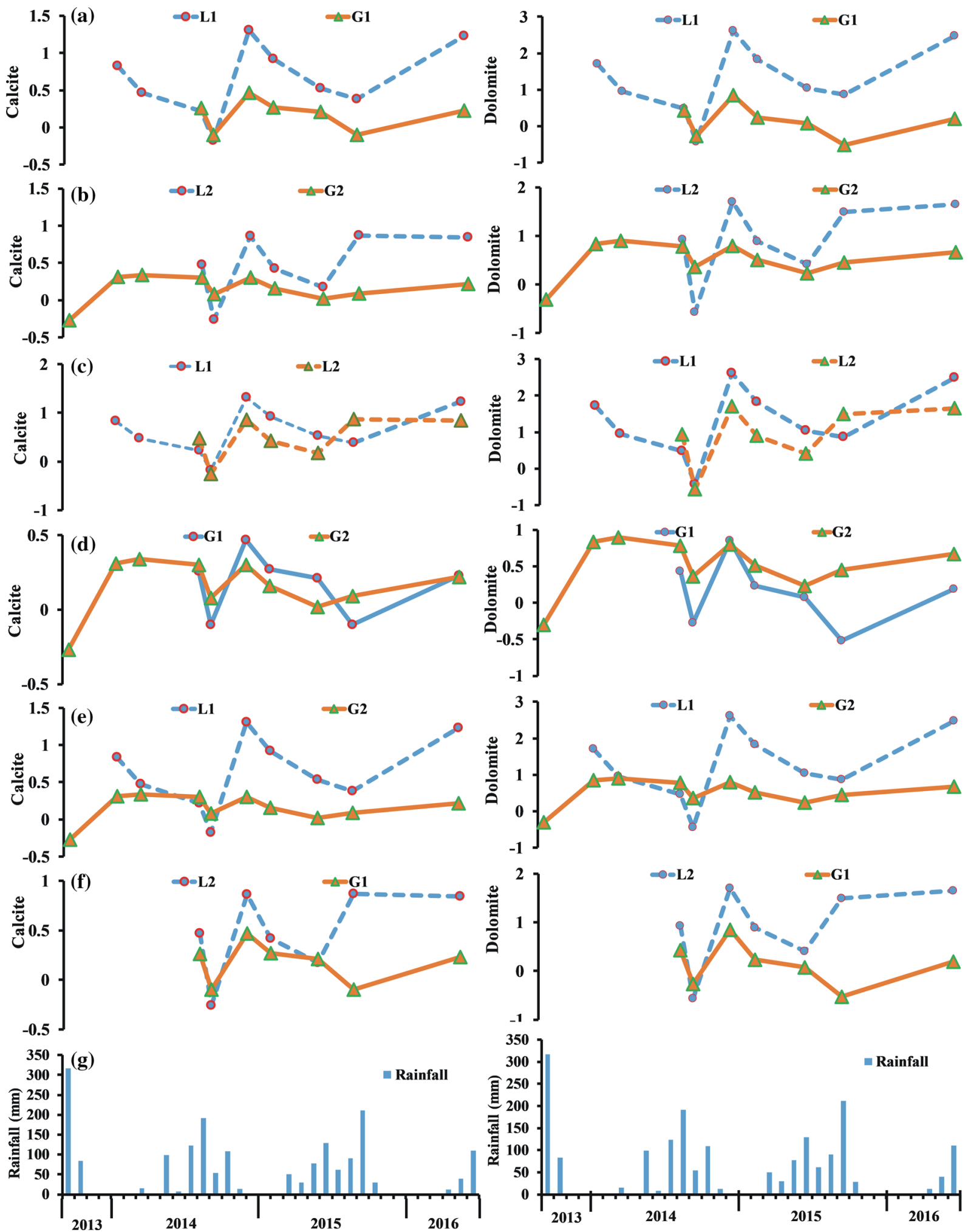

Figure 6. Comparison between the temporal variation of the SI with respect to rainfall: (a) L1 lake-G1 well, (b) L2 lake-G2 well, (c) L1 lake-L2 lake, (d) G1 well-G2 well, (e) L1 lake-G2 well, (f) L2 lake-G1 well and (g) temporal variation of rainfall.

with respect to the minerals present in the aquifer system. Mineral phases such as calcite and dolomite were considered owing to the presence of carbonate minerals in limestone rock. Table 3 shows the minimum and maximum mineral SIs observed from the PHREEQC.

Temporal variation of SI was prepared to understand the interaction process and is compared with 
the rainfall data, which is a major controlling factor for mineral saturation level. The carbonate minerals such as calcite and dolomite show an increasing trend during monsoon due to the dissolution of limestone rock. Comparison between the mineral SI of lake water and groundwater collected during several periods of sampling was plotted to understand the effects of lake water over groundwater and vice versa. In this study, six different comparisons were interpreted to understand the interaction process which include (i) L1 lake-G1 well, (ii) L2 lake-G2 well, (iii) L1 lake-L2 lake, (iv) G1 well-G2 well, (v) L1 lake-G2 well and (vi) L2 lake-G1 well.

Comparison between upstream region (L1-G1) and downstream region (L2-G2) reveals that a higher degree of interaction was observed in the downstream region (figure $6 \mathrm{a}$ and $\mathrm{b}$ ). In downstream region (L2-G2), the influence of lake water over groundwater is dominant during the monsoon due to rainfall recharge. Figure 6(c and d) indicates that lake water (L1-L2) and groundwater (G1-G2) express a similar pattern in the SI value indicating a strong correlation that depicts the common source of origin. Cross-comparison of lake water and groundwater (L1-G2 and L2G1) (figure 6e and f) expresses a strong correlation during the monsoon and less in postmonsoon. This indicates that recharge from L2, which was dominant in monsoon, will inverse during summer (i.e., groundwater in the upstream region recharge the L2 during the dry season).

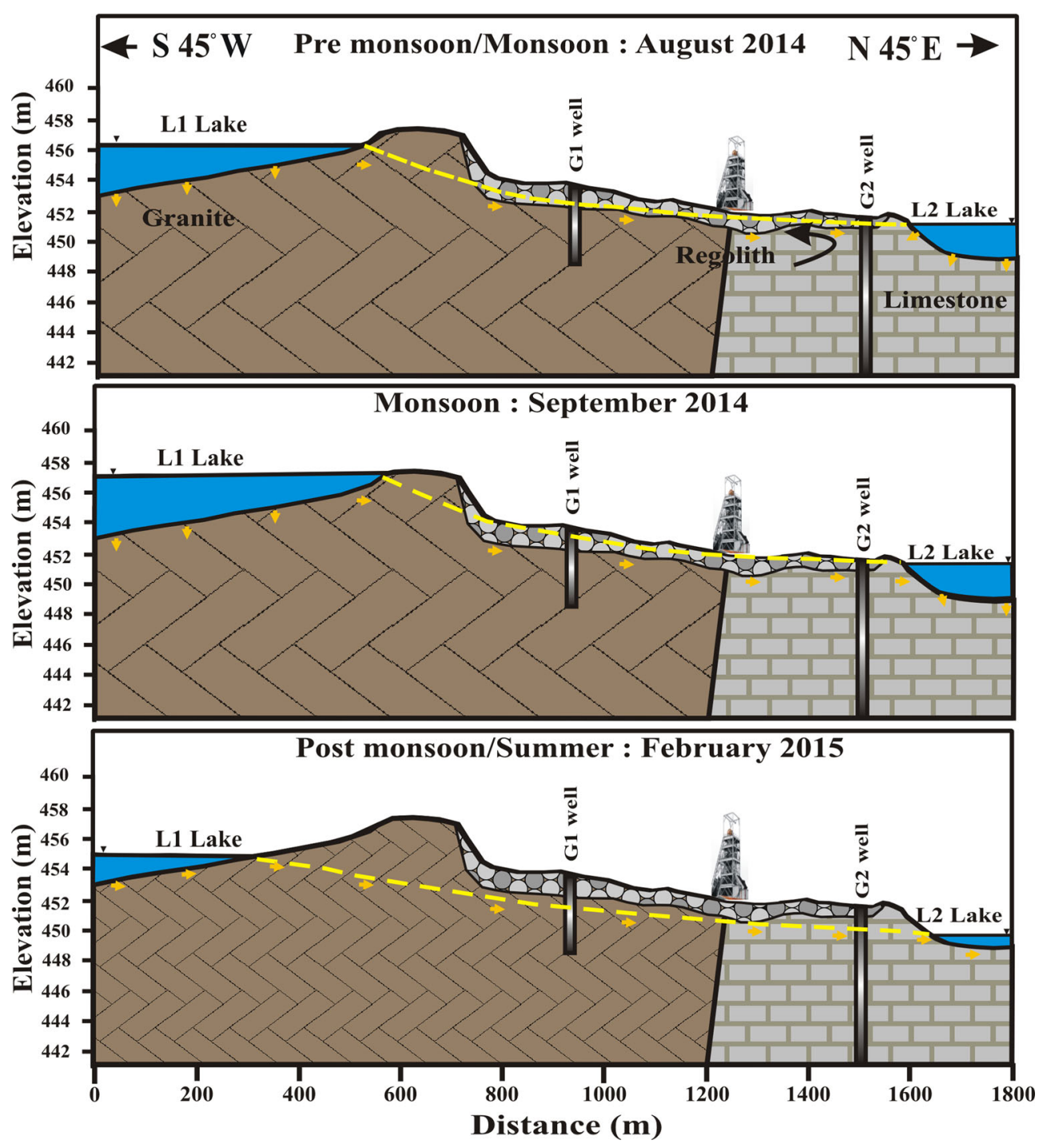

Figure 7. Schematic view of surface water and groundwater interaction near the uranium mineralised zone. 


\subsection{An idealised interaction process based on SI value}

Based on the comparison between the SI values of lake water (L1-L2) and its adjacent groundwater (G1-G2), the following interpretations are made:

(i) The SI value of L2 and G2 in the downstream region follows similar pattern due to same source and continuous recharge from the lake L1.

(ii) Degree of interaction between the lake (L2) and the groundwater (G2) is higher in the beginning of monsoon due to the recharge from L2, which occurs only during the onset of monsoon.

(iii) A similar trend of SI value was observed in groundwater of upstream (G1) and downstream (G2) indicating that the groundwater (G2) has evolved from G1.

(iv) Interaction between G1-G2 and L2 is higher during summer, which indicates that L2 is recharged from groundwater (G2) which is recharged by G1.
With the above results, various schematic diagrams were prepared to understand the interaction between surface water and groundwater near the uranium mineralised region (figure 7).

\subsection{Hydrogeochemical evolution by inverse modelling}

Inverse modelling was performed with three simulations (L1-G1, G1-G2 and G2-L2) (figure 8) along the same flow path with the primary mineral phases including aragonite, biotite, calcite, chlorite, coffinite, dolomite, gypsum, halite, $\mathrm{K}$-feldspar, plagioclase, quartz and uraninite which are reported by Chaki et al. (2005) and Patnaik et al. (2016) for this study region. Analytical values (major ions and uranium) of the water samples for each period were used to represent the initial and final solutions along the flow direction. Figure 8 shows the suitable model which has been selected based on the criteria of 'the sum of residuals and maximum fractional error' from all the models generated by PHREEQC. It represents

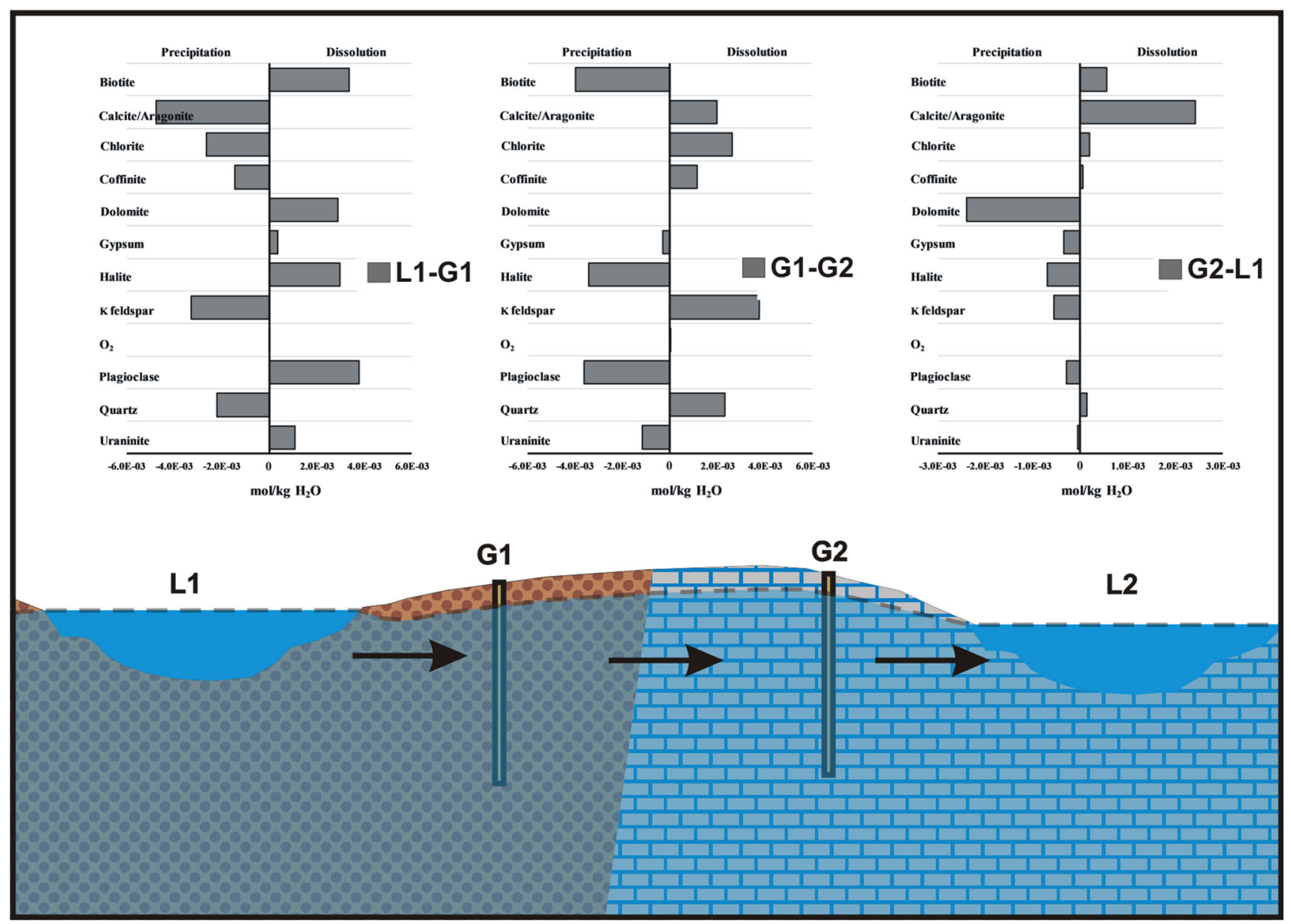

Figure 8. Hydrogeochemical evolution/phase mole transfer along the flow line. 

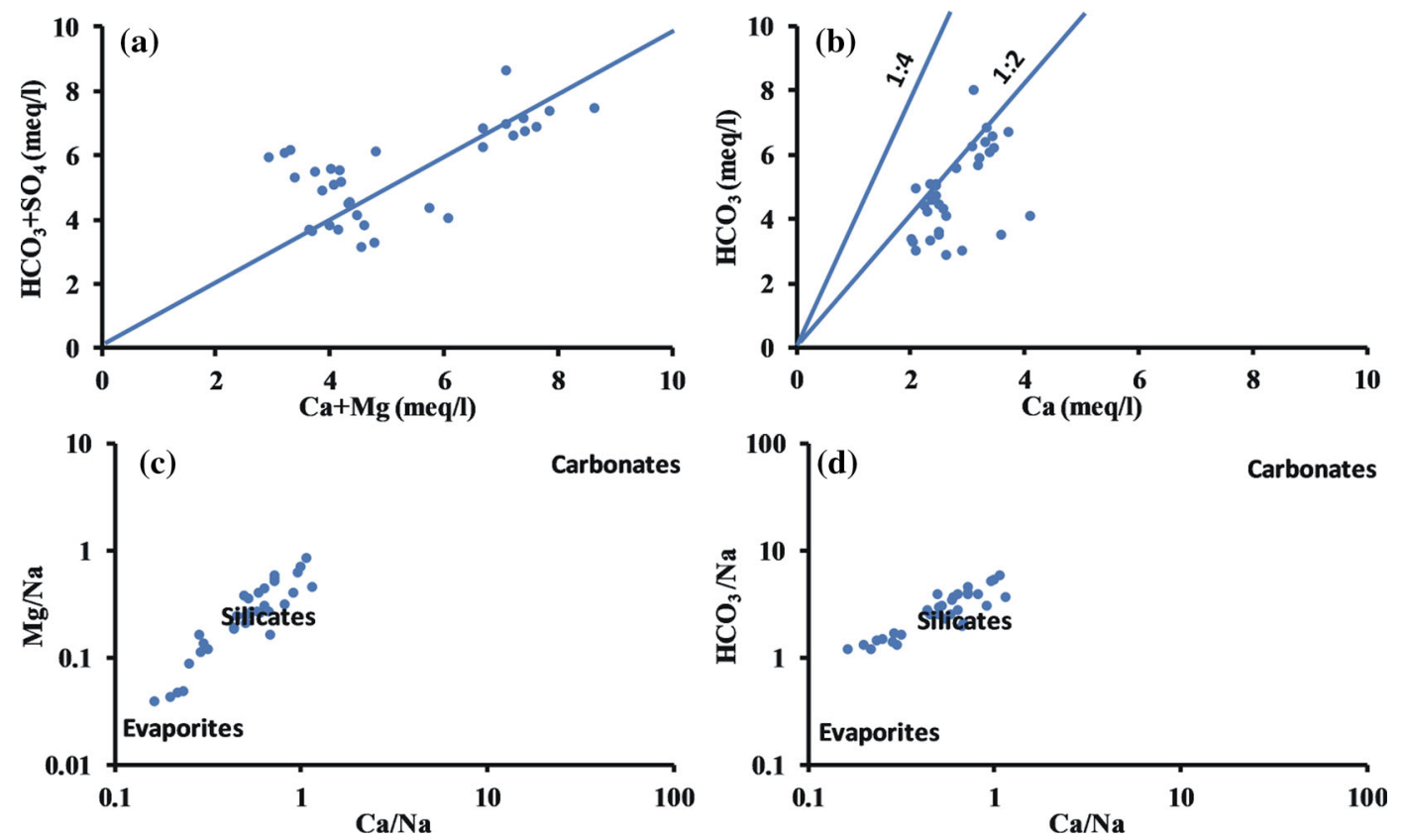

Figure 9. Bivariate plots indicating weathering trends: (a) $\mathrm{Ca}+\mathrm{Mg}$ vs. $\mathrm{HCO}_{3}+\mathrm{SO}_{4}$, (b) $\mathrm{Ca}$ vs. $\mathrm{HCO} 3,(\mathbf{c}) \mathrm{Ca} / \mathrm{Na}$ vs. $\mathrm{Mg} / \mathrm{Na}$ and (d) $\mathrm{Ca} / \mathrm{Na}$ vs. $\mathrm{HCO}_{3} / \mathrm{Na}$.

most possible combinations of reactants and products that are responsible for the hydrogeochemical evolution. In upstream region (L1-G1), precipitation of aragonite, calcite, quartz, K-feldspar and chlorite indicates the dominance of silicate weathering and carbonate weathering (figure 8). Since G1 is located in the agricultural land, the precipitation of gypsum and halite was observed along the flow path of G1-G2, which is derived from the irrigation return flow that is concentrated with the ions such as sodium and sulphate which are present in fertilisers and calcium from the soils that are derived from the adjacent carbonate rocks. From G2 to L2, the precipitation of carbonates, plagioclase, coffinite, gypsum and halite indicates the combined process of weathering and dissolution of evaporites computed by the inverse modelling which is also confirmed by the bivariate plot (figure 9). Figure 9(a) indicates that the points falling along the equiline may have originated from weathering of sulphate and carbonate minerals as suggested by Datta and Tyagi (1996). Figure 9(b) suggests that the points falling along 1:2 line have resulted from weathering of calcite (Mackenzie and Garrels 1971; Holland 1978). Figure 9(c and d) suggests that both silicate and evaporites are responsible for the changes in hydrogeochemistry of both the surface water and groundwater. The present study region is highly complex with respect to geology; the reactions that are responsible for the changes in hydrogeochemistry of water do not result from a single source, but from multiple sources which are depicted in figure 9 . Since the precipitation and dissolution kinetics of silicate minerals are slow, the moles released from these minerals are very less.

\section{Conclusions}

Hydrogeochemical modelling was used to understand the interaction between surface water and groundwater in a uranium mineralised region. Hydrogeochemically, surface water and groundwater were mainly of mixed $\mathrm{Ca}-\mathrm{Mg}-\mathrm{Cl}$ type except in the groundwater of upstream region which is of $\mathrm{Na}-\mathrm{Cl}$ type. Uranium species in surface water and groundwater was dominated by $\mathrm{UO}_{2}\left(\mathrm{CO}_{3}\right)_{3}^{4-}$ and $\mathrm{UO}_{2}\left(\mathrm{CO}_{3}\right)_{2}^{2-}$ hexavalent complexes. The lake on the western side always contributes to groundwater recharge, whereas during most part of the year groundwater is discharged to the lake on the eastern side. The rainfall results into change in the geochemical nature of water in the lake by way of changing the saturation indices from oversaturated to undersaturated level. The precipitation and dissolution of carbonate minerals were the major reactions that are responsible for the changes in the hydrogeochemistry in comparison with silicate minerals. Hence, carbonate 
weathering, silicate weathering and irrigation return flow are the dominant processes that govern the hydrogeochemical evolution in this region during the interaction process. Thus, the geochemical modelling helped to understand the temporal changes in the interaction between surface water and the groundwater in a uranium mineralised region which cannot be estimated by simple water level measurements.

\section{Acknowledgements}

The author would like to thank the Board of Research in Nuclear Sciences, Department of Atomic Energy, Government of India (grant no. 2009/36/ 71-BRNS/1690) for their financial support.

\section{References}

Achar K K, Pandit S A, Natarajan V, Kumar M K and Dwivedy K K 2001 Bhima Basin, Karnataka, India, uranium mineralisation in the Neoproterozoic. Assessment of uranium deposit types and resources - A worldwide perspective; International Atomic Energy Agency (IAEA), Technical Documents (TECDOC)-1258, Vienna, pp. 129140.

Ala-aho P, Rossi P M, Isokangas E and Kløve B 2015 Fully integrated surface-subsurface flow modelling of groundwater-lake interaction in an esker aquifer: Model verification with stable isotopes and airborne thermal imaging; J. Hydrol. 522 391-406.

ANZECC 2000 Australian and New Zealand guidelines for fresh and marine water quality; Australian and New Zealand Environment and Conservation Council (ANZECC) and Agriculture and Resource Management Council of Australia and New Zealand (ARMCANZ); Canberra, pp. 1-3.

Ayenew T, Kebede S and Alemyahu T 2008 Environmental isotopes and hydrochemical study applied to surface water and groundwater interaction in the Awash River basin; Hydrol. Process. 22(10) 1548-1563.

Belkhiri L, Boudoukha A, Mouni L and Baouz T 2010 Application of multivariate statistical methods and inverse geochemical modeling for characterization of groundwater - A case study: Ain Azel plain (Algeria); Geoderma 159(3) 390-398.

Bernhard G, Geipel G, Brendler V and Nitsche H 1996 Speciation of uranium in seepage waters of a mine tailing pile studied by time-resolved laser-induced fluorescence spectroscopy (TRLFS); Radiochim. Acta 74(s1) 87-92.

Booth C J 2006 Groundwater as an environmental constraint of longwall coal mining; Environ. Geol. 49(6) 796-803.

Brindha K and Elango L 2014 Geochemical modelling of the effects of a proposed uranium tailings pond on groundwater quality; Mine Water Environ. 33(2) 110-120.

Chaki A, Pannerselvam A and Chavan S J 2005 Uranium exploration in the Upper Proterozoic Bhima basin,
Karnataka, India - A new target area; International Atomic Energy Agency (IAEA), CN, p. 128.

Chaki A, Purohit R K and Mamallan R 2011 Low grade uranium deposits of India - A bane or boon; Energy Proc. 7 153-157.

Chandramouli C and General R E 2011 Census of India. Rural urban distribution of population, provisional population total; Office of the Registrar General and Census Commissioner, New Delhi, India.

Datta P S and Tyagi S K 1996 Major ion chemistry of groundwater in Delhi area: Chemical weathering processes and groundwater flow regime; J. Geol. Soc. India 47179 188.

Dongarra G 1984 Geochemical behaviour of uranium in the supergene environment; In: Uranium Geochemistry, Mineralogy, Geology, Exploration and Resources; Springer, Dordrecht, pp. 18-22.

Durov S A 1948 Natural waters and graphic representation of their composition; Dokl. Akad. Nauk. SSSR $5987-$ 90.

Eary L E, Runnells D D and Esposito K J 2003 Geochemical controls on ground water composition at the Cripple Creek mining district, Cripple Creek, Colorado; Appl. Geochem. 18(1) 1-24.

Federico C, Pizzino L, Cinti D, De Gregorio S, Favara R, Galli G, Giudice G, Gurrieri S, Quattrocchi F and Voltattorni N 2008 Inverse and forward modelling of groundwater circulation in a seismically active area (Monferrato, Piedmont, NW Italy): Insights into stress-induced variations in water chemistry; Chem. Geol. 248(1) 14-39.

Hein J R, Perkins R B, McIntyre B R, Jasinski S M, Lee W H, Causey J D, Piper D Z, Murchey B L, Evans J G and Knudsen A C 2004 Handbook of Exploration and Environmental Geochemistry Life (ed.) James R Hein, Vol. 8, 3-635.

Holland H D 1978 The Chemistry of the Atmosphere and Oceans; Princeton University Press, Princeton, NJ.

Hsi C K D and Langmuir D 1985 Adsorption of uranyl onto ferric oxyhydroxides - Application of the surface complexation site-binding model; Geochim. Cosmochim. Acta 49 1931-1941.

$\mathrm{Hu} \mathrm{L}, \mathrm{Xu} \mathrm{Z}$ and Huang W 2016 Development of a rivergroundwater interaction model and its application to a catchment in northwestern China; J. Hydrol. 543 483500 .

Kale V S and Peshwa V V 1995 The Bhima Basin; GSI Publications, India.

Kale V S and Phansalkar V G 1991 Purana basins of peninsular India: A review; Basin Res. 3(1) 1-36.

Karunakara N, Yashodhara I, Kumara K S, Tripathi R M, Menon S N, Kadam S and Chougaonkar M P 2014 Assessment of ambient gamma dose rate around a prospective uranium mining area of south India - A comparative study of dose by direct methods and soil radioactivity measurements; Results Phys. 4 20-27.

Katz B G, Coplen T B, Bullen T D and Davis J H 1997 Use of chemical and isotopic tracers to characterize the interactions between groundwater and surface water in mantled karst; GroundWater 35(6) 1014-1028.

Kay D, Barbato J, Brassington G and de Somer B 2006 Impacts of longwall mining to rivers and cliffs in the southern coalfield; In: Coal 2009: Coal operators' conference 
(ed.) Aziz N, University of Wollongong \& the Australasian Institute of Mining and Metallurgy (AusIMMM), pp. 327336.

Lecomte K L, Pasquini A I and Depetris P J 2005 Mineral weathering in a semiarid mountain river: Its assessment through PHREEQC inverse modeling; Aquat. Geochem. 11(2) 173-194.

Mackenzie F T and Garrels R M 1971 Evolution of Sedimentary Rocks; W. W. Norton \& Co., New York.

Manoj S, Parimalarenganayaki S and Elango L 2017a Estimation of distribution coefficient of uranium in soil by batch tests; IOP Conf. Ser. Mater. Sci. Eng. 263(3) 032016.

Manoj S, Thirumurugan M and Elango L 2017b An integrated approach for assessment of groundwater quality in and around uranium mineralized zone, Gogi region, Karnataka, India; Arab. J. Geosci. 10(24) 557.

Martinez J L, Raiber M and Cox M E 2015 Assessment of groundwater-surface water interaction using long-term hydrochemical data and isotope hydrology: Headwaters of the Condamine River, southeast Queensland, Australia; Sci. Total. Environ. 536 499-516.

Mason C F 2014 Uranium and nuclear power: The role of exploration information in framing public policy; Resour. Energy Econ. 36(1) 49-63.

Nair S and Merkel B J 2011 Impact of alkaline earth metals on aqueous speciation of uranium (VI) and sorption on quartz; Aquat. Geochem. 17(3) 209-219.

Pabalan R T, Bertetti F P, Prikryl J D and Turner D R 1996 Uranium(VI) sorption onto selected mineral surfaces: Key geochemical parameters; Abstr. Pap. Am. Chem. S. 211 55-Geoc.

Paces J B and Wurster F C 2014 Natural uranium and strontium isotope tracers of water sources and surface watergroundwater interactions in arid wetlands - Pahranagat Valley, Nevada, USA; J. Hydrol. 517 213-225.

Pahar G and Dhar A 2014 A dry zone-wet zone based modeling of surface water and groundwater interaction for generalized ground profile; J. Hydrol. 519 2215-2223.

Parkhurst D L 1995 User's quide to PHREEQE - A computer program for speciation, reaction-path, advective transport, and inverse geochemical calculations; US Geological Survey (USGS) Water-Resources graphical user interface for the geochemical computer program Investigations Report.

Patnaik S, Hegde G N, Panneerselvam A, Verma M B, Mohanty R and Rai A K 2016 Geochemical behaviour of LREE, $\mathrm{Y}$ and $\mathrm{Zr}$ in uranium mineralized and non-mineralized granite from Darshanapur area in the Gogi-Kurlagere fault zone, Bhima basin, Yadgiri district, Karnataka; J. Geol. Soc. India 88(2) 151-158.

Rajmohan N and Elango L 2004 Identification and evolution of hydrogeochemical processes in the groundwater environment in an area of the Palar and Cheyyar River Basins, southern India; Environ. Geol. 46(1) 47-61.

Senthil K and Srinivasan R 2002 Fertility of Late Archaean basement granite in the vicinity of U-mineralized Neoproterozoic Bhima basin, peninsular India; Curr. Sci. 82(5) $571-576$.

Sharif M U, Davis R K, Steele K F, Kim B, Kresse T $\mathrm{M}$ and Fazio J A 2008 Inverse geochemical modeling of groundwater evolution with emphasis on arsenic in the Mississippi River Valley alluvial aquifer, Arkansas (USA); J. Hydrol. 350(1) 41-55.

Soulsby C, Malcolm I A, Youngson A F, Tetzlaff D, Gibbins C N and Hannah D M 2005 Groundwater-surface water interactions in upland Scottish rivers: Hydrological, hydrochemical and ecological implications; Scot. J. Geol. 41(1) 39-49.

Vance R, Hinton N, Huffman D, Harris F, Arnold N, Ruokonen E, Jakubick A, Tyulyubayev Z, Till W V, Woods $\mathrm{P}$ and Hall S 2014 Managing environmental and health impacts of uranium mining; Organisation for Economic Co-operation and Development (OECD) NEA.7062.

Voeckler H M, Allen D M and Alila Y 2014 Modeling coupled surface water-groundwater processes in a small mountainous headwater catchment; J. Hydrol. 517 1089-1106.

Yi L, Ma B, Liu L, Tang G and Wang T 2016 Simulation of groundwater-seawater interaction in the coastal surficial aquifer in Bohai Bay, Tianjin, China; Estuarine Coast. Shelf Sci. 177 20-30. 